\title{
FACTORS IMPACTING ON THE NEGOTIATION \\ OF MUTUAL RECOGNITION ARRANGEMENTS/ AGREEMENTS OF AUTHORIZED ECONOMIC OPERATOR PROGRAMS: A LITERATURE REVIEW ${ }^{1}$
}

This paper will review relevant literature with the aim to identify potential factors in the negotiation process of mutual recognition agreements/arrangements (MRA) of authorised economic operator (AEO) programs for future research. AEOs are defined in the the SAFE Framework of Standards to Secure and Facilitate Global Trade (SAFE Framework) as those companies or individuals who meet specified compliance standards and show a demonstrated commitment to supply chain security. Meanwhile, MRAs are the means through which two Customs administrations recognise each other's validation and authorisations of AEOs and agree to provide mutual trade facilitation benefits to their AEOs.

Negotiationappears to be a common activity in modern society. After the terrorist attacks on 11th September 2001 in the United States (US), the international community has witnessed an emerging type of international negotiation which is the negotiation to reach an AEO MRA. The review of literature concludes thatthere appear to be challenges that exist in AEO MRA negotiations. Those challenges are associated with many factors in negotiations, such as political will, trust (or confidence) in trading partners' regulation environment, etc. Therefore, there is a need for an future empirical research for further understanding of how and to what extent these factors impacting on such negotiation process and outcome.

Key words: mutual recognition agreement, authorized economic operator, supply chain security, trade facilitation, customs cooperation, customs-business partnership.

JEL Classification: F02, F15, F23.

Mr Tuan Dung PHAM,

PhD Candidate,

Centre for Customs and Excise

Studies,

Charles Sturt University

tupham@csu.edu.au

\section{Introduction}

Negotiation is regarded as a common and formal form of communication that takes place between at least two parties to exchange proposals. Negotiation agenda covers a wide range of activities within political, security, trade, culture, education and environment spectrum. Since the $11^{\text {th }}$ September terrorist attacks in the United States, a new form of international negotiations has emerged and significantly increasedwhich is thenegotiations for achieving mutual recognition agreements of AEO programs.

Before the terrorist attacks, various customs administrations across the world had developed customs compliance programs or trade facilitation programs with

\footnotetext{
${ }^{1}$ Подяка: Я вдячний моїм науковим керівникам професору Девіду Віддовсону та д-р Михайлу Кашубському за підтримку та вказівки щодо підготовки огляду літератури, який став основою для цього документу
} 
the main focus on facilitating international trade.Authorized traders who are compliant with customs regulations would be provided with many benefits such as fast-track clearance of goods or others as recommended in the Revised Kyoto Convention.Then the attacks happened and could be seen as a turning point or game-changing event for governments and the international community to reshape regulatory environments for security reasons at the national, regional and global level (Carter 2014). The US responded to secure global supply chains with the launch of the Customs-Trade Partnership against Terrorism (C-TPAT).

Internationally, the World Customs Organization (WCO) adopted the SAFE Framework of Standards to Secure and Facilitate Global Trade (SAFE Framework) in 2005 consisting of key concepts of Authorised Economic Operator (AEO) and Mutual Recognition Agreement/ Arrangement (MRA) for the aim of promoting end-to-end supply chain security and creating internationally-linked authorised economic operator (AEO) programs as a trade facilitation measure. Many WCO member countries which have signed the Letter of Intent to implement the SAFE Framework, then attempt to develop AEO programs and ensure that all security criteria must be regulated and complied with the SAFE Framework (World Customs Organisation 2014).

AEO MRAs reflect a highlighted aspect of customs to customs network arrangements (U.S. Customs and Border Protection and Directorate-General for Taxation and Customs Union 2013). Further, MRAs have been acknowledged as a key factor for the effectiveness of operational AEO programs (Widdowson 2016) while theyare also regarded as a principal driver for many customs administrations to develop national AEO programs (Ireland 2009).

There are many potential benefits from operational MRAs consisting of the elimination of the need for AEO validation and authorization in countries of importation, the avoidance of duplication of requirements and inspections. The 2017 edition of the compendium of AEO programs recorded a significant increase of signed and negotiated MRAs across the world and stated that this demonstration will contribute to harmonisingthe approach to achieve bilateral and plurilateral recognition agreements (World Customs Organisation 2017).

Although every effort has been made by many WCO members, it would be a lot of challenges to make progress in the mutual recognition of AEO programs(Mikuriya 2007). The WCO calls on its members for having a standardized approach as a "solid platform" to AEO authorization due to its significant role in the development of bilateral, regional and international mutual recognition agreements of AEOs(World Customs Organisation 2015). The organisation also plays a vital role in the development of tools and instruments for promoting and initiating national AEO programs and mutual recognition of AEO programs(World Customs Organisation 2007).

However, it would be also acknowledged about the current circumstances that many countries have many concluded MRAs or ongoing negotiations while others are not ready to get involved or still struggle with their first MRA negotiations. There are obstacles associated with many factors in MRA negotiations, such as compatibility with the SAFE Framework, trust level, and political will. This literature review thus aims to gain a deep insight into the body knowledge of MRA negotiations. In doing so, negotiation literature will be reviewed to provide an overview of negotiations. Further, various factors will be discussed with regard to their impacts on AEO MRA negotiations.

\section{Overview of negotiation studies}

It is widely accepted among scholars and practitioners that negotiation is a multi-staged, cooperative process or a sequence of events for discussing proposals and reaching an agreement from different viewpoints of at least two parties (Kissinger 1969, Casse 1981, De Mesquita 
2004, Wertheim n.d.) in which they could be individuals, groups or nations. So negotiationhas become commonplace than ever before and presentedin a wide variety of fields, such as political, economic, education(Belshek n.d.), environment(Mace, Mrema et al. 2007) within bothnational and international settings(Mautner-Markhof 1989).

It is widely believed that most negotiations would be confidential which likely lead to insufficient primary source of data for research purpose (Bailer 2009). Negotiation studies often focus on strategies, approaches, processes, tactics, and outcomes(Alfredson and Cungu 2008, Saee 2008, Bailer 2009, Mansbridge and Martin 2013, Katz, Kochan et al. 2015, Brett and Thompson 2016, Weiler 2017). However, scholars in the field would attempt to utilise different methodologies in their studies. From the qualitative side, Sanches Neves, Liboni et al. (2013) obtains a qualitative approach with case studies to explore factors that motivate negotiators and how these factors affect negotiations while

Esther and Olukayode (2018) research cultural influences on negotiations and would like to have more explanations to research questions by using a qualitative approach. In the meantime, Weiler (2017) utilises quantitative research methods to measure relevant actors (power resources, bargaining strategies, etc.) against the outcome of negotiations. A quantitative approach is also used by Wood (2017) to demonstrate the results of negotiations significantly affected by noneconomic and economic factors. Nonetheless, there is still negotiation studiesemploying mixed methods, such as Olughor (2014).

Recent research studies and explores factors influencing the negotiation style,tactic, process, outcome(Ocran 1985, Bontadini 1989, Grunert 1989, Lang 1989, Lundstedt 1989, Plantey 1989, Poortinga and Hendriks 1989, Rinehart 1989, Holzinger 2001, Asian Development Bank 2008, Saee 2008, O'Brien and Gowan 2012, Mansbridge and Martin 2013, Sanches Neves, Liboni et al. 2013, Meerts 2015, Ahammad, Tarba et al. 2016, Brett and Thompson 2016, Stelzer 2016, Ko and Kwak 2017, Weiler 2017, Belshek n.d., Wertheim n.d.). A general assumption from these studies is that there are different factors affecting the outcome of specific negotiations although certain overlapping factors are also identified. In many of these negotiation studies, the cultural factor is frequently mentioned as an important factor (Ocran 1985, Mainardes, Nunes et al. 2013, Mansbridge and Martin 2013, Ahammad, Tarba et al. 2016, Belshek n.d.). Other factors are also analysed such as trust (Saee 2008, Mainardes, Nunes et al. 2013, Brett and Thompson 2016), national interest (Khroustalev 1989), social, political, economic setting (Ocran 1985), negotiators' skills (Asian Development Bank 2008), training of international negotiators (Bontadini 1989, Mastenbroek 1989), geography, geopolitics, governmental structures, economic indicators, legal and educational systems (Quinney 2002). Therefore, Mautner-Markhof (1989) emphasises influencing factors subject to its own international negotiation setting that:

It is necessary to consider the processes associated with international negotiations in the context of their cultural and political environments. Negotiationsare dependent not only on the system in which they are embedded but also onthe various perceptions of those involved. Thus, it is important to identify anddeal with the impacts of cultural, political, and psychological factors on international negotiations.

In a globalised world, international negotiations have developed both in number and diversity (Mautner-Markhof 1989). Many authors emphasise their researches on the topic of international negotiations (Mautner-Markhof 1989, Saee 2008, Mainardes, Nunes et al. 2013, Meerts 2015, Drahos 2017, Weiler 2017). Meerts (2015)stipulates that international negotiations could take place between parties from private or public sectors and makes use of the terms "diplomatic 
negotiation" for indicating negotiations between nations. Saee (2008) and Lewicki, Saunders et al. (2006) mention the level of complexity and difficulty of international negotiations which are attributed several factors such as different laws, regulations, standards, business practices, and cultural differences Saee (2008) or categorised factors into environmental (such as international economics, instability) and immediate contexts. Meanwhile, Mainardes, Nunes et al. (2013) states that international negotiations have more risks than domestic negotiations due to factors such as laws, norms, cultural differences, personal values, personalities or negotiating styles. Nevertheless, Drahos (2017) emphasises "international negotiations as a means of diffusion of regulatory capitalism".

There has been a growing number of AEO MRA negotiations among countries across the globe in the last decade. In essence, MRAs mean bilateral or plurilateral understandings in the form of agreements or arrangments (Aigner 2010, Karlsson 2017). Such agreements include verification procedures such as implementation, evaluation, and maintaining MRAs (U.S. Customs and Border Protection and Directorate-General for Taxation and Customs Union 2013). This mechanism needs a close collaboration among customs administrations for entering MRAs negotiations and for recognising each other partner's AEO programs in terms of validation and authorization processes.

\section{Factors impact on the AEO MRA negotiations}

In recent years, numerous studies have attempted to investigate factors that impact on the AEO MRA negotiations from varying perspectives. Some studies emphesised on economic factors by using empirical methods (Kim 2017) while others presented concepts, such as compatibility of AEO programs with the SAFE Framework on MRA negotiations (Fletcher 2007, Harrison and Holloway 2007, Aigner 2010, National Board of Trade 2010, Polner 2010, Altemöller 2011, Lánská and Vittek 2012, Hintsa 2013, Carter 2014, Karlsson 2017), or national sovereignty (Altemöller 2011). This section aims to identify factors impacting on the negotiation of AEO MRAs from existing literature.

To facilitate the understanding of a broad range of factors, studies on negotiation often categorise factors depending on their similar attributes (Mainardes, Nunes et al. 2013).The review of literature on the AEO MRA negotiations has been conducted and identified a variety of potential factors. Based on the nature of each factor, they are then categorized into a number of groups consisting of political, regulatory, organizational-culture, technical, economic, and psychological characteristics to facilitate the construction of conceptual research framework.

\section{Political characteristics}

Political characteristics include areas such as government policy, political structure and stability,political support, trade control, import restrictions and tariffs, regulation or deregulation, and the belief of politicians towards specific countries in their international relations. Many authors examine the influence of political factors on the negotiation of AEO MRAs which involve political will, national sovereignty, trade facilitation and control (non-tariff barriers, import clearance time as indicators), and trust in trading partners' regulatory environment(Donner and Kruk 2009, Aigner 2010, National Board of Trade 2010, Altemöller 2011, Hintsa 2013, Chuah 2014, Ariadna 2016, Chan and Holler 2016, Widdowson 2016, Kim 2017).

The National Board of Trade (2010)focuses on the development of AEO-like programs to date in many key trading nations across the world and noted that a solution for both parties in MRA negotiations could depend on political will and real cooperation of both parties. In a different view, Altemöller (2011) identifies challenges for MRAs negotiations attributing to national sovereignty. National AEO programs often represent nations' priority of security which is consequently 
connected to national sovereignty. This thus may well become "political impediments" for MRAs. Similarly, Chuah (2014)in a recent study also mentions the case that one negotiating partner could take advantage of MRAs to influence other partners' regulations.

Besides that, non-tariff barriers (NTBs) such as import licensing, customs and administrative entry procedures, standards, pre-shipment inspections are not mentioned in any AEO programs which may be problematic to the negotiation of MRAs. Questions raised in this situation that once MRAs are on operational but in a later stage, certain NTBs would be required by a party to protect its domestic market (Ariadna 2016). On the other hand, Kim (2012) in Kim (2017) argues that AEO MRAs can be combined with Free Trade Agreements (FTA) to eliminate the effects of NTBs. Additionally, Kim (2017) notes that the likelihood of achieving AEO MRA is higher within countries with a lower level of NTBs.

There are not many empirical studies on the field of AEO MRAs, but Lee and Shao (2014) conducts a compelling study based on empirical data collected from prior and post-AEO MRA and found that import clearance time for AEO companies which is faster than non-AEO companies before MRAs and significantly reduced after MRAs, as well as the number and percentage of goods examination for AEOs being substantially reduced after MRAs. In the meanwhile, Kim (2017)finds the correlation between AEO MRAs and import clearance time (p. 24).

Table 1

Factors with political characteristics are extracted from the existing literature

\begin{tabular}{|c|c|c|}
\hline Factor & Explanation & Author \\
\hline Political will & $\begin{array}{l}\text { In the aspect of this research, political } \\
\text { will refers to the intention, desire or } \\
\text { commitment of political actors to work on } \\
\text { "all phases of the process of preparation } \\
\text { and implementation of a policy", such as } \\
\text { government initiative, choice of policy, } \\
\text { public commitment and allocation of } \\
\text { resource, continuity of effort, monitoring of } \\
\text { implementation (Abazović and Mujkić 2015). }\end{array}$ & $\begin{array}{l}\text { (Fletcher 2007, Harrison and } \\
\text { Holloway 2007, Aigner 2010, } \\
\text { National Board of Trade 2010, } \\
\text { Polner 2010, Altemöller 2011, } \\
\text { Lánská and Vittek 2012, Hintsa } \\
\text { 2013, U.S. Customs and Border } \\
\text { Protection and Directorate-General } \\
\text { for Taxation and Customs Union } \\
\text { 2013, Carter 2014, Karlsson 2017, } \\
\text { World Customs Organisation 2018) }\end{array}$ \\
\hline $\begin{array}{c}\text { National } \\
\text { sovereignty }\end{array}$ & $\begin{array}{l}\text { National sovereignty refers to the power } \\
\text { or the authority of a nation to control its } \\
\text { internal matters without foreign interference } \\
\text { (such as making, executing, and applying } \\
\text { laws) and protecting its independence, } \\
\text { territory and political structure (Steinberg } \\
\text { 2013). }\end{array}$ & $\begin{array}{l}\text { (Altemöller 2011, Chuah 2014, } \\
\text { Tegneman and Tryggvason 2015) }\end{array}$ \\
\hline $\begin{array}{l}\text { Non-tariff } \\
\text { barriers }\end{array}$ & $\begin{array}{l}\text { There are not only customs but other } \\
\text { border agencies at the border. Regulations } \\
\text { and procedures which require excessive } \\
\text { documentation by these agencies are likely } \\
\text { to create non-tariff barriers to international } \\
\text { trade. }\end{array}$ & (Ariadna 2016, Kim 2017) \\
\hline $\begin{array}{l}\text { Import } \\
\text { clearance time }\end{array}$ & $\begin{array}{l}\text { Import clearance time refers to the amount } \\
\text { of time that it takes to clear import goods } \\
\text { from customs/border agencies. }\end{array}$ & (Lee and Shao 2014, Kim 2017) \\
\hline
\end{tabular}




\section{Regulatory characteristics}

These factors with regulatory characteristics involve the presence and changes in laws, administrative guidelines for the implementation of AEO programs and the achievement of AEO MRAs. They may well include the compatibility of AEO programs with the SAFE Framework, the focus of AEO programs, the scope of AEO programs, and dispute resolution procedures.

The compatibility of AEO programs with the SAFE Framework means the level of AEO programs to be compatible with the SAFE Framework and its instruments which could affect MRA negotiations. Many studies noted the importance of the compatibility of AEO programs with the SAFE Framework on MRA negotiations (Fletcher 2007, Harrison and Holloway 2007, Polner 2010, Altemöller 2011, Lánská and Vittek 2012, Hintsa 2013). This is because the SAFE Framework sets out global standards and principles for developing AEO programs, and encourages Customs administrations to implement them in a uniform manner. Further, Hintsa (2013) and Polner (2010) regards the SAFE Framework playing the role of a model for harmonized implementation in every contracting party. In the meantime, other researches emphasise that if WCO members develop AEO programs with provisions different from the recommendations of the SAFE Framework which may cause those AEO programs divergent and incompatible with the SAFE Framework(Aigner 2010, National Board of Trade 2010, Lánská and Vittek 2012, Karlsson 2017). Therefore, the updated SAFE Framework (version 2018) emphasises that "If the respective countries are signatories to SAFE, the critical Customs to Business Pillar fundamentals will already be in place to foster a healthy negotiating environment." (World Customs Organisation 2018).

The SAFE Framework foster this process by providing guidelines for WCO members to establish AEO programs (World Customs Organisation 2012). Many studies are in favour of the application of these guidelines to harmonise countries' security initiatives (Fletcher 2007) and to becompatible with the SAFE Framework standards. If so, their AEO programs could be recognized across the world(Altemöller 2011) and this facilitates the acceptance of other parties' initiatives in mutual recognition processes (Lánská and Vittek 2012). Additionally, MRAs will be fostered by common standards and uniform criteria from countries' AEO programs in negotiations (Altemöller 2011, Lánská and Vittek 2012).

Lánská and Vittek (2012) states that the example of EU-US MRA represents a favourable approach to negotiations of different programs based on similar principles such as the data exchange, not their philosophy. This finding seems to be reinforced by a decision signed on May 4, 2012 between the US and the EU for mutually recognizing the C-TPAT program in the U.S. and the AEO program in the EU in a compatible manner and operators holding a membership status of these two programs are equally treated, "to the extent practicable and possible" (U.S. Customs and Border Protection and Directorate-General for Taxation and Customs Union 2013). More especially, Carter (2014) emphasises "the understanding of similarities of security standards in different nations" and notes that several customs compliance programs which are recognised as equivalent to another party's AEO programs in concluded MRAs. It appears that Carter's findings are less convincing and the reason for this will be discussed below.

The scope of AEO programs is regarded as the choice of countries to develop AEO programs with their priority for export only, import only or both export and import. The National Board of Trade (2010) gives a reference from the SAFE Framework that both import 
and export flows need to be taken into account in mutual recognition of AEO programs. Apart from the scope, the focus of AEO programs refers to the structure of customs-business partnership programs whereby they are developed and included with a layer of trade compliance provisions or a layer of security provisions, or both layers. This could be because there are different initiatives or concepts for "trusted trader", including the Revised Kyoto Convention, the SAFE Framework, and the Trade Facilitation Agreement. While an AEO and AEO MRAs are defined in the SAFE Framework which create international standards for customs administrations to launch AEO programs and seek AEO MRAs with other customs administrations, other programs with only a compliance layer could be regarded as a customs compliance program or a customs facilitation program with no common specified criteria and standards (World Customs Organisation 2014, World Customs Organisation 2016).

In the National Board of Trade (2010), the EU sets real mutuality (for AEO programs with both export and import) as a goal for MRA negotiations, Karlsson (2017)however emphasises on a challenge to MRA negotiations if AEO programs lack maturity. The reason isgiven byKarlsson (2017) that there will be a situation of unbalanced benefits to exchange in two programs which make it difficult to "provides more benefits that already exist in the national programs". Nonetheless, the maturity of an AEO program could be subtle when taking an example from Australia as this country launched the Trusted Trader program and then obtained their first MRA with New Zealand nearly at the same time. So it appears that the maturity of an AEO program would be simply a synthesis of other factors, such as the scope, the focus, etc.

Widdowson, Blegen et al. (2014) have a different view with a study that reviews 'Accredited Operator' (AO) schemes on operation or being implemented worldwide and stresses on security standards in AEO programs as principal criteria for mutual recognition with evidence from the potential of New Zealand-Australia MRAs. Because the sole scope of New Zealand's Secure Export Scheme (SES) is the security of exported cargo, and MRA between two countries could be achieved with only security standards in Australia' AEO program. Another example of this is the MRAs between New Zealand and the US.

It is recommended by the WCO that countries seeking AEO MRA partners should take into account whether their partners' respective programs are fully operational and consistent with security standards specified in the SAFE Framework. Furthermore, security components in their partners' AEO programs should have a "rigorous validation methodology" (World Customs Organisation 2018).

Chuah (2014) explains that dispute resolution procedures mean a mechanism which allows a partner of MRAs to exercise against irregularities involving AEO companies from other partners' programs. Two examples from Chuah (2014) including the EU-US and EUJapan agreements show the presence of such procedures thereby customs administrations can suspend the benefits provided to other partners' AEOs. However, reasons must be promptly given and there will be further consultations between two customs administrations. The author argues that these two agreements also present different provisions relating to dispute resolution procedures, but clearly demonstrate "how the suspension of benefits take place" and the possible impact on each other's relationship in MRAs. Although Chuah (2014) mentions the lack of dispute resolution procedures as a challenge of mutual recognition in the EU-China context, it is still unclear how this challenge can affect MRA negotiations. 
Table 2

Factors with regulatory characteristics are extracted from the existing literature

\begin{tabular}{|c|c|c|}
\hline Factor & Explanation & Author \\
\hline $\begin{array}{l}\text { Compatibility of } \\
\text { AEO programs } \\
\text { with the SAFE } \\
\text { Framework }\end{array}$ & $\begin{array}{l}\text { The compatibility with the SAFE } \\
\text { Framework refers to a status } \\
\text { by which national or regional } \\
\text { AEO programs should be based } \\
\text { on similar principles, uniform } \\
\text { criteria or common standards } \\
\text { as recommended by the SAFE } \\
\text { Framework, such as AEO } \\
\text { certification, assessment, approval, } \\
\text { monitoring of AEO status, post- } \\
\text { authorization mechanism. }\end{array}$ & $\begin{array}{l}\text { (Fletcher 2007, Harrison and } \\
\text { Holloway 2007, Aigner 2010, } \\
\text { National Board of Trade 2010, Polner } \\
\text { 2010, Altemöller 2011, Lánská } \\
\text { and Vittek 2012, World Customs } \\
\text { Organisation 2012, Hintsa 2013, U.S. } \\
\text { Customs and Border Protection and } \\
\text { Directorate-General for Taxation } \\
\text { and Customs Union 2013, Carter } \\
\text { 2014, Karlsson 2017, World Customs } \\
\text { Organisation 2018) }\end{array}$ \\
\hline $\begin{array}{l}\text { The scope of AEO } \\
\text { programs }\end{array}$ & $\begin{array}{l}\text { The scopeof AEO programs is } \\
\text { regarded as countries choose to } \\
\text { develop AEO programs with their } \\
\text { priority for export only, import } \\
\text { only or both export and import. } \\
\end{array}$ & $\begin{array}{l}\text { (National Board of Trade } 2010 \text {, } \\
\text { Karlsson 2017) }\end{array}$ \\
\hline $\begin{array}{l}\text { The focus of AEO } \\
\text { programs }\end{array}$ & $\begin{array}{l}\text { The focus of AEO programs } \\
\text { refers to the structure of Customs- } \\
\text { business partnership programs } \\
\text { whereby they include a layer of } \\
\text { trade compliance provisions or } \\
\text { a layer of security provisions, or } \\
\text { both layers. }\end{array}$ & $\begin{array}{l}\text { (Widdowson, Blegen et al. 2014, } \\
\text { World Customs Organisation 2014, } \\
\text { World Customs Organisation 2016, } \\
\text { World Customs Organisation 2018) }\end{array}$ \\
\hline $\begin{array}{l}\text { Dispute resolution } \\
\text { procedures }\end{array}$ & $\begin{array}{l}\text { This factor refers to "the } \\
\text { procedures to be followed if one } \\
\text { MRA partner finds irregularities } \\
\text { involving the AEOs of the } \\
\text { other partner country's AEO } \\
\text { Programme" (Chuah 2014). }\end{array}$ & (Chuah 2014) \\
\hline
\end{tabular}

\section{Organisational-culture characteristics}

Organisational culture-related factors comprise a set of the shared values and beliefs by a nation, a trading community which provide guidance or lead the ways community members organizing and interacting with each other towards their objectives(Cooke and Szumal 1993). Previous authors identified several factors related to organizational-culture, comprised of highlevel internal commitment, resource allocation, MRA training, the awareness of traders of MRA concept, utilisation, and benefits, trader's satisfaction with MRA benefits (Kim 2017, World Customs Organisation 2018).

High-level internal commitment identified in the WCO Mutual Recognition Strategy Guide (the WCO Strategy Guide) is regarded as an important factor influencing MRA negotiations. This means that when a country identifies potential MRA partners and between them existing larger agreements (e.g. Customs Mutual Assistance Agreement (CMAA), Supply Chain Security Agreement, Letter of Intent), MRA negotiations are likely to be successful due to obtaining high-level interest and political support. The tool also recommends that internal commitments at senior level should be previously achieved to support efficiently an MRA negotiation (World Customs Organisation 2018). 
However, resource allocation factor has not been broadly discussed in the literature that could impact MRA negotiations, except the WCO Mutual Recognition Strategy Guide. This guide mentioned that prior to reaching other customs administrations for MRA engagement, one customs administration should consider the proposed timeframe for MRA negotiation process, the availability of human and financial resources (World Customs Organisation 2018). Therefore, when two or more countries decide to initiate into AEO MRA negotiations, it is also important that they have to take into account several other factors such as timeframe, human resources, budget for such MRA negotiations.

A critical finding from Kim (2017)is that there is a significantly low level of the awareness on MRA concept, utilisation and benefits among the private sector, and a lower satisfaction on MRA benefits from AEO companies than expectation. Sharing the same view of the significance of raising the awareness about AEO MRAs with Kim (2017), the WCO Mutual Recognition Strategy Guide indicates that MRA training to the private sector will be the key to such objective. Additionally, training materials (e.g. brochure) should be developed by MRAengaging administrations (World Customs Organisation 2018).

Table 3

Factors with organisational-culture characteristics are extracted from the existing literature

\begin{tabular}{|l|l|l|}
\hline \multicolumn{1}{|c|}{ Factor } & \multicolumn{1}{|c|}{ Explanation } & \multicolumn{1}{c|}{ Author } \\
\hline $\begin{array}{l}\text { High-level internal } \\
\text { commitment }\end{array}$ & $\begin{array}{l}\text { High-level internal commitments to } \\
\text { support MRA negotiations }\end{array}$ & $\begin{array}{l}\text { (World Customs } \\
\text { Organisation 2018) }\end{array}$ \\
\hline Resource allocation & $\begin{array}{l}\text { Allocation of time, human and finance } \\
\text { for MRA negotiation process. }\end{array}$ & $\begin{array}{l}\text { (World Customs } \\
\text { Organisation 2018). }\end{array}$ \\
\hline MRA training & $\begin{array}{l}\text { MRA training and materials provided to } \\
\text { customs officers and the private sector }\end{array}$ & $\begin{array}{l}\text { (World Customs } \\
\text { Organisation 2018). }\end{array}$ \\
\hline $\begin{array}{l}\text { The awareness of traders of } \\
\text { MRA concept, utilisation, } \\
\text { and benefits }\end{array}$ & $\begin{array}{l}\text { This factor refers to the knowledge and } \\
\text { experience of international traders on } \\
\text { MRA concept, utilisation, and benefits. }\end{array}$ & $\begin{array}{l}\text { (Kim 2017, World } \\
\text { Customs Organisation } \\
\text { 2018) }\end{array}$ \\
\hline $\begin{array}{l}\text { Satisfaction with MRA } \\
\text { benefits }\end{array}$ & $\begin{array}{l}\text { This factor refers to the satisfaction of } \\
\text { AEO companies with MRA benefits } \\
\text { provided under an AEO MRA. }\end{array}$ & (Kim 2017) \\
\hline
\end{tabular}

\section{Technical characteristics}

Certain technical factors including relevant data exchange, data protection, and integrity could affect the negotiation of MRAs. Weerth (2011), Weerth (2015) states that due to issues related to data exchange and data protection, the number of MRAs negotiations still stands at a low level. Hintsa (2013) emphasises that data exchange is the critical aspect of any MRAs. If there is an absence of this factor, MRAs would not work. Kim (2017) argues that data exchange and protection are "prerequisite of AEO MRA negotiation" which could affect to trust in partner countries' security and a nation tends to have MRA negotiation with partners which possess secure IT environments (p. 25).

Although many authors discussed about legal aspects of data protection, data integrity and exchange Weerth (2011), Weerth (2015)Hintsa (2013)Kim (2017)(Chuah 2014)Aigner (2010) 
Ireland (2011)Chan and Holler (2016)National Board of Trade (2010), just National Board of Trade (2010) recommends the technical aspect regarding data exchange need to take into account in MRA negotiations. While the legal side considers "how to overcome problems" as some information could be confidential or privacy and data protection, the technical side relates the questions of "where it must be agreed", "what data is required", and "how it is to be transferred" to overcome any struggle in the implementation stage of MRA agreements.

Hintsa (2013) presents another potential bottleneck in MRA negotiations is that how the process from data exchange of customs declarations and validation of AEOs to the stage of applying benefits to eligible AEO companies should be clearly described in MRAs. Further, Hintsa (2013) emphasises "The different methods of identifying or referencing AEOs in different countries can make this very problematic, but not insurmountable."

Aigner (2010) notes that countries intend to achieve MRAs could consider carefully about their equivalent standards in AEO programs, requirements of timely data exchange, and also approach to controls, integrity, data protection as these issues could affect to their negotiating partners' trust or common understandings. Another consideration in this aspect is sensitive information for being exchanged or accessible. A study byIreland (2011) points out several controversial viewpoints in MRA negotiations, such as data exchange, data privacy, and scanners in foreign ports. Chan and Holler (2016)suggests an Automated Electronic Data Exchange System and Compatible Trader Identification Number (TIN) Systems for identifying other partners' AEOs and granting eligible benefits and incentives. These systems will be expected to facilitate MRAs negotiations.

Meanwhile, the guidelines for developing a mutual recognition arrangement/agreement presents little issues related to data exchange and the use of risk management. This could be partly understood that a partner of MRAs will be mandated to have access into other partners' systems and to manage the risk concerning data mishandling, breach of security and noncompliance with customs regulations (Chuah 2014).

Table 4

Factors with technical characteristics are extracted from the existing literature

\begin{tabular}{|c|l|l|}
\hline Factor & \multicolumn{1}{|c|}{ Explanation } & \multicolumn{1}{c|}{ Author } \\
\hline $\begin{array}{c}\text { Privacy } \\
\text { and Data } \\
\text { protection }\end{array}$ & $\begin{array}{l}\text { Privacy and data protection refer to the } \\
\text { individual's privacy, the confidentiality of } \\
\text { information/data. Privacy must be protected } \\
\text { and individuals have the right to have access } \\
\text { to their personal data held to verify its } \\
\text { accuracy. }\end{array}$ & $\begin{array}{l}\text { (Aigner 2010, National Board of } \\
\text { Trade 2010, Ireland 2011, Weerth } \\
\text { 2011, Weerth 2015, Chan and } \\
\text { Holler 2016, Kim 2017) }\end{array}$ \\
\hline Data exchange & $\begin{array}{l}\text { Data exchange refers to the exchange of data } \\
\text { such as customs declarations, validation of } \\
\text { AEO status among Customs administrations. }\end{array}$ & $\begin{array}{l}\text { (Aigner 2010), Ireland (2011), } \\
\text { (Hintsa 2013, Kim 2017) }\end{array}$ \\
\hline Data integrity & $\begin{array}{l}\text { Data integrity refers to the assurance of the } \\
\text { accuracy and consistency of data in any system } \\
\text { which stores, processes, or retrieves data. }\end{array}$ & (Aigner 2010) \\
\hline
\end{tabular}

\section{Economic characteristics}

Economic characteristics include factors with regard to the current international trade, the national economy or level of development among countries that are taking part in AEO MRA negotiations. Although these economic-related factors seem to play a critical role in such negotiations, there are just a 
few studies on these factors, such as Kim (2017). Interestingly, Kim (2017)findsa greater probability of AEO MRAs related to economy sizes, export value in bilateral trade (p. 24). The limitation identified in Kim (2017) is only the use of secondary data which could reduce the validation of this research.

Table 5

Factors with economic characteristics are extracted from the existing literature

\begin{tabular}{|c|c|c|}
\hline Factor & Explanation & Author \\
\hline Economic size & $\begin{array}{c}\text { In this research, this factor refers to the gross domestic } \\
\text { product (GDP) one country can generate in one fiscal year. }\end{array}$ & (Kim 2017) \\
\hline $\begin{array}{c}\text { Export volume in a } \\
\text { bilateral trade }\end{array}$ & $\begin{array}{c}\text { This factor refers to the export revenue that a country } \\
\text { generates from exporting goods into another country. }\end{array}$ & (Kim 2017) \\
\hline
\end{tabular}

\section{Psychological characteristics}

Psychological elements discussed in the literature as factors impacting all negotiations which include trust, assumptions, decisions, attitudes one party makes about the other (Wertheim n.d.). Trust in trading partners' regulatory environment is likely an important element for mutual recognition of AEO programs (Widdowson 2016). Whilst Donner and Kruk (2009)presents trust level among negotiating partners may well be an obstacle in negotiations of MRAs. Hintsa (2013) stresses further that trust could result from close cooperation between customs administrations in which partners in MRA negotiations must have an equivalent regulatory environment (each other's audits, control, and authorisations) and adequate security level. Conducting an investigation of AEO programs in APEC countries, Chan and Holler (2016) notes that there are a number of impediments for achieving plurilateral mutual recognition agreements such as trust on other partner's control mechanisms, data protection while currently, operational MRAs witnessed a divergence even on their general provisions which could impede international trade.

Similarly, Aigner (2010) states that "mutual recognition is based on the trust" between countries and that negotiation of MRAs only happen if there is confidence in each other's security measures. Many AEO mutual recognition arrangements or agreements have been concluded or are being negotiated among customs administrations that they could have sufficient trust in each other's audit, ongoing control, and authorisation. Also, Aigner (2010) notes that to achieve plurilateral or global mutual recognition, it is difficult to ensure that all parties have a similar trust level on each other's programs, control, and audits. However, the National Board of Trade (2010) claims that customs administrations could not "trust blindly" when they negotiate MRAs. Trust would take time to build up, therefore, suggests the WCO ensure the equivalence of AEO programs among its members. If there is a uniform implementation of standards, trust in each other' authorisations will be rooted.

Table 6

Factors with psychologicalcharacteristics are extracted from the existing literature

\begin{tabular}{|c|l|l|}
\hline Factor & \multicolumn{1}{|c|}{ Explanation } & \multicolumn{1}{c|}{ Author } \\
\hline $\begin{array}{c}\text { Trust (or confidence) } \\
\text { in trading partners' } \\
\text { regulatory } \\
\text { environment }\end{array}$ & $\begin{array}{l}\text { Trust (or confidence) in trading partners' regulation } \\
\text { environment refers to a firm belief whereby a } \\
\text { nation can have whether confidence (sufficient } \\
\text { trust) in the reliability, truth, or ability of other } \\
\text { nations' regulatory environment (such as audits, } \\
\text { controls mechanisms, andauthorisations) and/or } \\
\text { adequate security level (such as data protection). }\end{array}$ & $\begin{array}{l}\text { (Donner } \\
\text { Chan and Holler 2016, } \\
\text { Widdowson 2016) }\end{array}$ \\
\hline
\end{tabular}




\section{Conclusion}

From the review of the literature, there appear to be challenges that exist in AEO MRA negotiations. While literature indicates conceptual findings of challenges to achieve AEO MRAs associated with certain factors, no previous empirical research to identify and analyse factors impacting on MRA negotiations. Also, there is no clear evidence as to whether the above mentioned are the actual factors and how all identified factors would impact on MRAs negotiations.

The challenges are associated with many factors in negotiations, such as compatibility with the SAFE Framework, trust level, and political will. Therefore, this literature review will be an important ground for identifying and further analysing if there are any other factors, howand to what extent these factors impacting on such negotiation outcome in any future research. These researches should alsoidentify and recommend ways to overcome such challenges and to facilitate AEO MRA negotiations which ensure international trade facilitation and international supply chain security.

\section{References:}

1. Abazović, D. and A. Mujkić, Eds. (2015). Political will: a short introduction case study Bosnia and Herzegovina. Sarajevo, Friedrich-Ebert-Stiftung.

2. Ahammad, M. F., S. Y. Tarba, Y. Liu, K. W. Glaister and C. L. Cooper (2016). "Exploring the factors influencing the negotiation process in cross-border M\&A." International Business Review25(2): 445-457.

3. Aigner, S. (2010). "Mutual recognition of authorised economic operators and security measures." World Customs Journal4(1): 47-54.

4. Alfredson, T. and A. Cungu (2008). Negotiation Theory and Practice: A Review of the Literature Food and Agriculture Organization of the United Nations.

5. Altemöller, F. (2011). "Towards an international regime of supply chain security: an international relations perspective." World Customs Journal5(2): 21-34.

6. Ariadna, A. (2016). Costs and benefits of facilitation and security in trade. Master Thesis, Erasmus University.

7. Asian Development Bank (2008). "How to Design, Negotiate, and Implement a Free Trade Agreement in Asia."

8. Bailer, S. (2009). What factors determine bargaining power in EU negotiations?, UCD Dublin European Institute.

9. Belshek, J. A. (n.d.). The influence of culture on the negotiation styles of Bristish Students.

10. Bontadini, P. L. (1989). Negotiations for Results: How to Develop Related Executive Skills. Processes of International Negotiations. F. Mautner-Markhof. England, Westview Press.

11. Brett, J. and L. Thompson (2016). "Negotiation." Organizational Behavior and Human Decision Processes136: 68-79.

12. Carter, A. S. (2014). AEO and C-TPAT in the light of Art. XX GATT, with emphasis on lit. (b) and lit. (d). 1527168 M.B.A., Hochschule fuer Angewandte Wissenschaften Hamburg (Germany).

13. Casse, P. (1981). Training for the cross-cultural mind. Washington, DC, Society for Intercultural Education, Training and Research.

14. Chan, C. and R. Holler (2016). Study of APEC best-practices of authorized economic operator programs. APEC Policy Support Unit, Asia-Pacific Economic Cooperation

15. Sub-Committee on Customs Procedures.

16. Chuah, J. (2014). "The EU-China mutual recognition agreement of authorised economic operators (AEOs)-A paradigm of customs cooperation?" International Trade Law \& Regulation(4): 86-95.

17. Cooke, R. and J. Szumal (1993). "Measuring normative beliefs and shared behavioural expectations in organisations: the reliability and validity of the organisational culture inventory." Psychological Reports72(3): 1299-1330. 
18. De Mesquita, B. B. (2004). "Negotiation in International Politics." Conflict Management and Peace Science21: 155-158.

19. Donner, M. and C. Kruk (2009). Supply chain security guide. Washington, The International Bank for Reconstruction and Development.

20. Drahos, P., Ed. (2017). Regulatory Theory: Foundations and applications. Australia, ANU Press.

21. Esther, O. D. and O. A. Olukayode (2018). "Cultural Influences on Negotiations between the Chinese and the British in Higher Educational Settings in the UK." Trends in Technical and Scientific Research2(5): 1-6.

22. Fletcher, T. (2007). “Authorised economic operator (AEO) programs: IBM's perspective." World Customs Journal1(2).

23. Grunert, H. (1989). Negotiations in Our Time. Processes of International Negotiations. F. Mautner-Markhof. England, Westview Press.

24. Harrison, M. and S. Holloway (2007). Customs and supply chain security: 'The demise of risk management?'. Asia-Pacific Economic Cooperation's Annual Conference of APEC Centers, Melbourne, Australia, April.

25. Hintsa, J. (2013). "Authorised economic operator \& mutual recognition agreement study for Royal Thai Customs."

26. Holzinger, K. (2001). "Negotiations in Public-Policy Making: Exogenous Barriers to Successful Dispute Resolution.” Journal of Public Policy 21(1): 71-96.

27. Ireland, R. (2009). "The WCO SAFE framework of standards- Avoiding excess in global supply chain security policy.” WCO Research Paper3.

28. Ireland, R. (2011). "The customs supply chain security paradigm and 9/11: Ten years on and beyond." WCO Research Paper18.

29. Karlsson, L. (2017). "Back to the future of customs: A new AEO paradigm will transform the global supply chain for the better." World Customs Journal11(1): 23-34.

30. Katz, H., T. Kochan and A. Colvin (2015). “The Negotiations Process and Structures.” Labor relations in a globalizing world 79-101.

31. Khroustalev, M. A. (1989). Some Methodological Problems of Modeling International Negotiations. Processes of International Negotiations. F. Mautner-Markhof. England, Westview Press.

32. Kim, B. (2017). Analysis on the factors that affect AEO MRA. Master of International Studies, Seoul National University.

33. Kissinger, H. A. (1969). “The Vietnam Negotiations.” Foreign Affairs47(1): 211-234.

34. Ko, B. and R.-S. Kwak (2017). "The Impact of Domestic Political Factors on International Trade Negotiation Outcomes: A Focus on Free Trade Agreements." Journal of International Trade \& Commerce13(4): 17-32.

35. Lang, W. (1989). Multilateral Negotiations: The Role of Presiding Officers. Processes of International Negotiations. F. Mautner-Markhof. England, Westview Press.

36. Lánská, M. and P. Vittek (2012). Comparison of security ensurance of supply chain in EU and U. S. Carpathian Logistics Congress, Priessnitz SpaJesenik, TANGER Ltd.

37. Lee, C. H. and W. Shao (2014). Research on AEO and AEO MRA effects.

38. Lewicki, R., D. Saunders and B. Barry, Eds. (2006). Negotiation. Singapore, McGraw-Hill/ Irwin.

39. Lundstedt, S. B. (1989). Conceptions of the Trade Negotiation Process. Processes of International Negotiations. F. Mautner-Markhof. England, Westview Press.

40. Mace, M. J., E. M. Mrema, C. Bruch and C. Salpin (2007). Guide for Negotiators of Multilateral Invironmental Agreements, UNEP Division of Environmental Law and Conventions.

41. Mainardes, E. W., A. J. Nunes and P. Pinheiro (2013). "International negotiations with Brazil: An essay about culture factor “ African Journal of Business Management 7(39): 4067-4077.

42. Mansbridge, J. and C. J. Martin (2013). Negotiating Agreement in Politics. United States, American Political Science Association. 
43. Mastenbroek, W. F. G. (1989). Training in International Negotiating: A Learning Instrument. Processes of International Negotiations. F. Mautner-Markhof. England, Westview Press.

44. Mautner-Markhof, F., Ed. (1989). Processes of international negotiations. London, Westview Press.

45. Meerts, P. (2015). Diplomatic Negotiation: Essence and Evolution. Netherlands, Clingendael Institute.

46. Mikuriya, K. (2007). "Supply chain security- the customs community's response." World Customs Journal1(2): 51-60.

47. National Board of Trade (2010). Mutual Recognition of AEO Programmes.

48. O'Brien, E. and R. Gowan (2012). What Makes International Agreements Work: Defining Factors for Success, New York University.

49. Ocran, T. M. (1985). "The process and outcome of negotiations with multinational corporations: A conceptual framework for analysis." Akron Law Review18(3): 405-434.

50. Olughor, R. J. (2014). "Influence of Culture on Negotiation Style." International Journal of Science and Research3(6): 653-658.

51. Plantey, A. (1989). Paradigms in International Negotiation: The Example of "Good Faith". Processes of International Negotiations. F. Mautner-Markhof. England, Westview Press.

52. Polner, M. (2010). "Compendium of Authorized Economic Operator (AEO) Programmes."

WCO Research Paper(8).

53. Poortinga, Y. H. and E. C. Hendriks (1989). Culture as a Factor in International Negotiations: A Proposed Research Project from a Psychological Perspective. Processes of International Negotiations. F. Mautner-Markhof. England, Westview Press. Peace.

54. Quinney, N. (2002). U.S. Negotiating Behavior. United States, United States Institute of

55. Rinehart, L. M. (1989). "Organizational and Personal Factors Influencing the Negotiation of Motor Carrier Contracts: A Survey of Shippers and Motor Carriers." Transportation Journal29(2): 4-14.

56. Saee, J. (2008). "Best Practice in Global Negotiation Strategies for Leaders and Managers in the 21st Century." Journal of Business Economics and Management9(4): 309-318.

57. Sanches Neves, M. B., L. B. Liboni, D. A. Defina and D. P. Martinelli (2013). "The Relationship between Negotiation Style and Motivation in Unpaid Negotiations: A Case Study in Brazil." International Journal of Business Administration4(3).

58. Steinberg, M. (2013). "Reforming the notion of national sovereignty by external intervention." Defense \& Security Analysis29(1): 68-75.

59. Stelzer, M. A. (2016). "Success Factors in Decision Making and Negotiation Processes for Raw Material Supply Transactions.” Procedia Economics and Finance39: 380-388.

60. Tegneman, O. and S. Tryggvason (2015). Authorised economic operator (AEO): Looking into the current perception and the future of the AEO program in Sweden. Master Degree Project in Logistics and Transport Management, University of Gothenburg.

61. U.S. Customs and Border Protection and Directorate-General for Taxation and Customs Union (2013). EU-US mutual recognition FAQ.

62. Weerth, C. (2011). "Authorized Economic Operator (AEO) in the World." Global Trade and Customs Journal6(7/8): 377-380.

63. Weerth, C. (2015). "AEO programmes worldwide: From MRAs to a general AEO agreement." Global Trade and Customs Journal10(6): 228-230.

64. Weiler, F. (2017). Preference Attainment: Why are some Countries more Successful in Negotiating the Earth's Climate?

65. Wertheim, E. (n.d.). "Negotiations and Resolving Conflicts: An Overview “.

66. Widdowson, D. (2016). "Managing the border: A transformational shift to pre-export screening." World Customs Journal10(2): 3-16.

67. Widdowson, D., B. Blegen, M. Kashubsky and A. Grainger (2014). "Review of accredited operator schemes: an Australian study." World Customs Journal8(1): 17-34. 
68. Wood, J. (2017). “An Industrial Sector Analysis of the Factors Influencing FTA Negotiation Outcomes.” Global Business Review18(4): 895-910.

69.

70. World Customs Organisation (2007). WCO SAFE Framework of Standards to secure and facilitate global trade.

71. World Customs Organisation (2012). Compendium of authorized economic operator programmes.

72. World Customs Organisation (2014). Compendium of authorized economic operator programmes.

73. World Customs Organisation (2015). WCO SAFE framework of standards to secure and facilitate global trade.

74. World Customs Organisation (2016). Compendium of authorized economic operator programmes.

75. World Customs Organisation (2017). Compendium of authorized economic operator programmes.

76. World Customs Organisation (2018). WCO Mutual Recognition Strategy Guide.

\title{
ФАКТОРИ, ЩО ВПЛИВАЮТЬ НА ПЕРЕГОВОРИ \\ ПРО УКЛАДАННЯ УГОДИ ПРО ВЗАСМНЕ ВИЗНАННЯ ПРОГРАМ \\ УПОВНОВАЖЕНИХ ЕКОНОМІЧНИХ ОПЕРАТОРІВ: ОГЛЯД ЛІТЕРАТУРИ
}

\author{
Туан Зунг ФАМ, \\ PhD кандидат, \\ Центр з вивчення питань митниці та акцизних зборів, \\ Університет Чарльза Стерна \\ tupham@csu.edu.au
}

У статті розглядається наукова література з метою визначення потенційних факторів при проведенні переговорного процесу про укладання угоди про взаємне визнання (УВВ) програм уповноважених економічних операторів (УЕО) для майбутніх досліджень. Уповноважені економічні оператори визначаються Рамковими стандартами безпеки та полегшення всесвітньої торгівлі (SAFE Framework) як компанії або особи, які контролюють та демонструють готовність забезпечити безпеку ланиюга поставок. У той же час, УВВ є засобом, за допомогою якого митні служби двох країн визнають законність та повноваження УЕО та погоджуються сприяти розвиткові взаємної торгівлі своїх УЕО.

Переговори стають звичайною діяльністю сучасного суспільства. Після терористичного нападу 11 вересня 2001 року у США, світова спільнота засвідчила становлення міжнародних переговорів з укладання УВВ УЕО. Огляд літератури засвідчує існування проблем під час проведення переговорів про УВВ УЕО. Вони пов'язані з багатьма факторами, такими як політична воля, довіра (або впевненість) у середовище регулювання відносин з торговельними партнерами тощчо. Відповідно, існує необхідність проведення емпіричних досліджень у майбутньому для більшого розуміння як та наскільки такі фактори впливають на процес та результат переговорів.

Ключові слова: угода про взаємне визнання, уповноважений економічний оператор, безпека ланцюга поставок, розвиток торгівлі, митна співпраця, партнерство «митницябізнес». 